\title{
Greenhouse localized heating powered by a polygeneration system
}

\author{
Evelia Schettini, ${ }^{1}$ Giovanni Puglisi, ${ }^{2}$ Fabiana Convertino, ${ }^{1}$ Fernando Antonio Cancellara, ${ }^{3}$ Giuliano Vox ${ }^{1}$ \\ ${ }^{1}$ Department of Agricultural and Environmental Science DISAAT, University of Bari; ${ }^{2}$ Technical Unit Energy \\ Efficiency, ENEA - Italian National Agency for New Technologies, Energy and Sustainable Economic Development, \\ C.R. Casaccia (RM); ${ }^{3}$ Department of Energy Efficiency Unit, Division Systems, Projects and Solutions for Energy \\ Efficiency, ENEA - Italian National Agency for New Technologies, Energy and Sustainable Economic Development, \\ Bari, Italy
}

\begin{abstract}
Energy consumption in greenhouse heating could reach up to $90 \%$ of the total energy requirement depending on the type of greenhouse, environmental control equipment and location of the greenhouse. The use of climate conditioning technologies that exploit renewable energy and the application of passive systems to improve the energy efficiency and the sustainability of the greenhouse sector are recommended. During winter 2020-2021, an experimental test was carried out at the University of Bari in a Mediterranean greenhouse heated by a polygeneration system, composed of a solar system and an air-water heat pump. Three localized heating systems were tested to transfer thermal energy close to plants of Roman lettuce. Heating pipes were placed inside
\end{abstract}

Correspondence: Evelia Schettini, Department of Agricultural and Environmental Science DISAAT, University of Bari, via Amendola 165/A, 70126 Bari, Italy.

Tel.: +39.080.5443060 - Fax: +39.080.5442977. E-mail: evelia.schettini@uniba.it

Key words: Air-water heat pump; climate control; renewable energy; solar collectors; sustainability.

Acknowledgements and funding: the contribution to programming and conducting this research was equally shared between the Authors within the competencies of the research groups. This work was conducted under the 'Piano Triennale di Realizzazione 2019-2021 della Ricerca di Sistema Elettrico Nazionale- Progetto 1.5 Tecnologie, tecniche e materiali per l'efficienza energetica ed il risparmio di energia negli usi finali elettrici degli edifici nuovi ed esistenti, Accordo di Programma Ministero dello Sviluppo Economico - ENEA funded by the Italian Ministry of Economic Development. This research has been developed in the framework of the activities of the "Centro Interdipartimentale di Ricerca per la Cooperazione allo Sviluppo' (CPS) of the University of Bari, Italy.

Received for publication: 20 May 2021.

Accepted for publication: 20 July 2021.

(C) Copyright: the Author(s), 2021

Licensee PAGEPress, Italy

Journal of Agricultural Engineering 2021; LII:1205

doi:10.4081/jae.2021.1205

This article is distributed under the terms of the Creative Commons Attribution Noncommercial License (by-nc 4.0) which permits any noncommercial use, distribution, and reproduction in any medium, provided the original author(s) and source are credited. the cultivation substrate in the underground pipe system and on the cultivation substrate in the laid pipe system. The third system consists of metal plates heated by steel tubes and placed in the aerial area of plants. A weather climatic station and a sensor system interfaced with a data logger for continuous data acquisition and storage were used. The plate system was the best for air temperature rising, as it allowed an increase of $3.6 \%$ compared to the set-up without any localised heating system. The underground pipe system was the best for the soil heating, as it achieved a temperature increase of $92 \%$. Localized soil heating systems contributed significantly to an earlier harvest by almost 2 weeks.

\section{Introduction}

Following the growing demand for high quality horticultural products, the greenhouse sector is interested in technologies and systems aimed to obtain an accurate microclimate control at every crop stage. The adequate microclimate for plant growth depends on the climate of the geographical area, the covering material, the growing season, and the cultivated species. Greenhouse covering materials are chosen mainly to maximise the penetration of solar radiation with little attention to thermal insulation (Fabrizio, 2012). Growers typically use fossil-fuelled air conditioning systems with a high environmental burden as well as high costs. Bibbiani et al. (2016) reported a consumption of fossil fuels for maintaining optimal greenhouse air temperature equal to about 5$6 \mathrm{~kg} \mathrm{~m}^{-2} \mathrm{yr}^{-1}$ in Southern Europe and to $60-80 \mathrm{~kg} \mathrm{~m}^{-2} \mathrm{yr}^{-1}$ in Central-Northern Europe. The yearly energy demand for greenhouse production is estimated at $220-320 \mathrm{MJm}^{-2}$ in Southern Europe and up to $3600 \mathrm{MJm}^{-2}$ in Northern Europe (Gorjian et al., 2021).

Costs for greenhouse climate control represent approximately $70-85 \%$ of the total cost, excluding labour costs. Energy consumption in greenhouse heating could reach up to $90 \%$ of the total energy requirement depending on the type of greenhouse, environmental control equipment and greenhouse location (Ahamed et al., 2019). Sethi and Sharma (2008) reviewed the heating technologies used in greenhouse production by discussing the main applications of each technology. Water storage, rock bed storage, phase change material storage, thermal screens, ground air collector and north wall storage can be used to increase greenhouse sustainability (Sethi and Sharma, 2008).

Technological solutions are advocated to reduce energy consumption and use of fossil fuels, so as to lower their associated environmental impacts (Hernández et al., 2017; Gorjian et al., 2021). The use of climate control technologies that exploit renewable energy sources (RES) and the application of passive systems 
for improving energy efficiency are key factors (Vox et al., 2008; Fabrizio, 2012; Vox et al., 2014; Cuce et al., 2016). RES and passive systems reduce both energy costs and $\mathrm{CO}_{2}$ emissions in the greenhouse sector (Barbaresi et al., 2020). Applicable renewable energy sources for greenhouse cultivation purposes are solar, wind, biomass, and geothermal heat. Gorjian et al. (2021) reported that several studies investigated the integration of agricultural greenhouses with individual renewable energy sources, even though additional studies are necessary on polygeneration systems powering greenhouse equipment.

The use of the solar thermal energy for greenhouse heating in southern Mediterranean countries was evaluated by several researchers (Bazgaou et al., 2021). The integration of a renewable energy source technology into a heating system which is not powered by renewable energy could overcome the intermittent supply of the renewable sources.

The greenhouse volume to be conditioned can be reduced using localized conditioning systems, but these techniques must be perfected and adapted to the different types of cultivation (Puglisi et al., 2019, 2020). The use of localized conditioning systems may require the introduction of thermal energy transmission methods, which have never been used in agriculture, as, for example, in the case of radiative surface systems. The aim of our research was to heat a greenhouse cultivation by means of a polygeneration system composed of a solar system and an air-water heat pump. Therefore, our research is intended to achieve a progress in the field of the exploitation of polygeneration systems to power greenhouse equipment. An innovative aspect of our study is the use of thermal energy distributed to the plants by three different localized systems. The experimental tests have shown that the volume to be conditioned can be reduced to less than $20 \%$ of the initial one with the use of the localized systems.

\section{Materials and methods}

\section{Experimental greenhouse}

The research activity was carried out at the experimental centre "P. Martucci" of the University of Bari. The centre is in Valenzano (Bari, Italy), latitude $41^{\circ} 01^{\prime} \mathrm{N}$, longitude $16^{\circ} 54^{\prime} \mathrm{E}$, altitude $85 \mathrm{~m}$ a.s.1. During winter 2020-2021, the greenhouse was heated by means of the polygeneration system composed of a solar system and an air-water heat pump (Figure 1). The arch-roofed experimental greenhouse was characterized by a galvanized steel supporting structure and a plastic covering film in ethylene-vinyl-acetate (EVA). The greenhouse had a length of $30.00 \mathrm{~m}$, a width of 10.00 $\mathrm{m}$, a ridge height of $4.45 \mathrm{~m}$ and a gutter height of $2.45 \mathrm{~m}$. Its longitudinal axis had a north-south orientation. There were openings along the side walls and at the ridge to allow natural ventilation.

The EVA covering film [Patilite E, P.A.T.I., San Zenone degli Ezzelini (TV), Italy] had a thickness of $0.21 \mathrm{~mm}$. Its radiometric characteristics were: solar total transmissivity equal to $74.9 \%$ and solar direct transmissivity equal to $40.7 \%$ in the wavelength range from 300 to $2500 \mathrm{~nm}$ and Long Wave Infrared (LWIR) greenhouse effect equal to $89.4 \%$ in the wavelength range from 7500 to 12,500 $\mathrm{nm}$. Plants in greenhouse were grown in rectangular pots $(1.00 \times 0.40 \times 0.40 \mathrm{~m})$ arranged transversely to greenhouse longitudinal axis (Figure 1). There were 8 rows with 6 pots each. The growing substrate was made of a mixture of soil and peat. Irrigation was provided to the plants by means of a drip irrigation system.

\section{Polygeneration heating system}

The polygeneration heating system tested was made up of a solar system and an air-water heat pump. The solar system was composed of solar field, hot water tank, dry cooler, pump, valves and piping. The solar field consists of 15 stationary solar collectors (model Sky PRO CPC 58-1800-20, Kloben, Verona, Italy) placed on the ground and south-facing. The collectors were installed with a tilt angle of $40^{\circ}$ to maximize the harnessing of the solar radiation. Each solar collector had 20 evacuated-tube pipes, with a gross area of $4.28 \mathrm{~m}^{2}$, an opening area of $3.81 \mathrm{~m}^{2}$ and an absorption area of $5.17 \mathrm{~m}^{2}$. A 2000-L. tank (model PVR-15/742, Pacetti, Ferrara, Italy) stored the hot water provided by the solar collectors. The dry cooler (Thermocold, Bari, Italy) was an emergency device used when the temperature of the water delivered by the solar field was higher than $95^{\circ} \mathrm{C}$.

The air-water heat pump [model ANLI $101 \mathrm{HX}$, AERMEC $\mathrm{SpA}$, Bevilacqua (VR), Italy] was a reversible outdoor inverter. The heat pump had a cooling capacity of $28.9 \mathrm{~kW}$ and a thermal power of $31.5 \mathrm{~kW}$. It produced both hot water and cold water that could be used for greenhouse heating and cooling. During the summer season the heat pump could work at full load up to an external air temperature of $42^{\circ} \mathrm{C}$.

Inside the greenhouse another 1000-L. tank (Cordivari srl, Teramo, Italy) was used to store hot water for greenhouse heating.

The solar collectors supplied hot water to the 2000-L. thermal storage tank. When the solar radiation was higher than $300 \mathrm{Wm}^{-2}$, the hot water flowed from the external tank to the tank located into the greenhouse. The water flow rate from the 2000-L. tank to the 1000 -L. greenhouse tank was equal to $0.0003 \mathrm{~m}^{3} \mathrm{~s}^{-1}$. The same water flow value was used to deliver thermal energy to the distribution pipes inside the greenhouse. These were galvanized insulated steel pipes with a diameter of $32.0 \mathrm{~mm}$.

The air-water heat pump worked automatically and continuously by integrating the hot water tank inside the greenhouse to keep the water in this tank at a temperature of $40^{\circ} \mathrm{C}$.

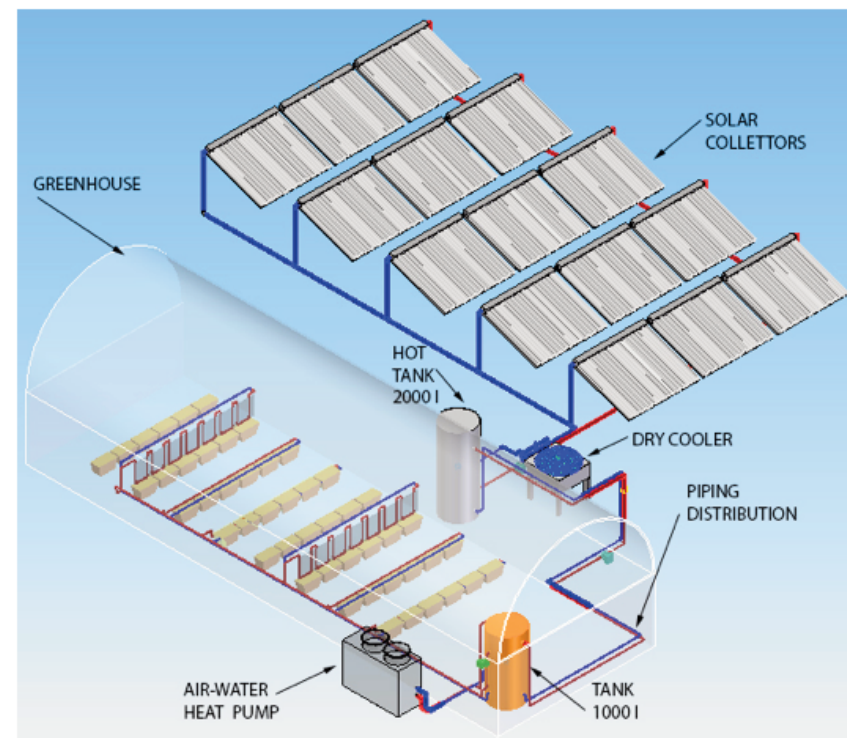

Figure 1. Polygeneration system with solar collectors and airwater heat pump at the University of Bari. 


\section{Heat localized distribution system}

The heating distribution system branched off from the hot water tank located inside the greenhouse to the plants. Hot water began to circulate in the pipes for localized heating, when the greenhouse air temperature was below $15^{\circ} \mathrm{C}$. The heat distribution system near the plants was made of galvanized steel pipes with a diameter of $12.7 \mathrm{~mm}$.

The water passed through the growing area and returned to the tank inside the greenhouse and from here to the external thermal storage tank and towards the air-water heat pump.

The use of localized heating system may require the introduction of thermal energy distribution systems, which have not yet been tested in agriculture. During winter 2020-2021, three different heat distribution systems close to plants were tested (Figure 2). The plant, with its growth and productivity, represents a bio-sensor able to record the performance of the climate conditioning system.

The first localized heat distribution system, coded as underground pipe, was made of polyethylene (PE) pipes, with a diameter of $16.0 \mathrm{~mm}$, and was placed inside the cultivation substrate. The pipes were placed $15 \mathrm{~cm}$ below the soil surface.

The second system, coded as laid pipe, was made of PE pipes, with a diameter of $16.0 \mathrm{~mm}$, and was located on the surface of the cultivation substrate.

The third system, coded as plate, consisted of metal plates heated by steel tubes, and was placed in the aerial area of the plants. The steel pipes, with a diameter of $12.7 \mathrm{~mm}$, were placed vertically above the cultivation pots near one of the longitudinal edges and in contact with the $0.5-\mathrm{mm}$ thick aluminium plates. There were also $3-\mathrm{cm}$ thick polystyrene panels for the rear insulation of the plates.

Underground pipes and laid pipes heated the growing medium. The plate system heated the air close to plants, while the presence of radiative surfaces influenced plant growth. Plants are certainly sensitive to the heat exchange, when exposed to high temperature radiant surfaces.

Radiometric tests were performed on the aluminium plate at the University of Bari. Tests were carried out by a FT-IR spectrophotometer (1760 X, Perkin Elmer Instruments, Norwalk, CT, USA), with a step of $4 \mathrm{~cm}^{-1}$, in the LWIR range between 2500 and $25,000 \mathrm{~nm}$. The emissivity coefficient in the LWIR range was calculated as the average value of the spectral emissivity in the wavelength range from 7500 to $12,500 \mathrm{~nm}$ (Vox et al., 2005; Schettini and Vox, 2012). This range corresponds to the wavelengths with the maximum emission of bodies at ambient temperature and is an indicator of the material ability to release and receive radiation and therefore disperse heat. The emissivity coefficient of the aluminium plate, evaluated as an average between 7500 and 12,500 nm, was equal to 0.234 .

\section{Data acquisition and storage}

The experimental farm was equipped with a weather climatic station and a sensor system interfaced with a data logger for continuous data acquisition and storage. Data were measured at a frequency of $60 \mathrm{~s}$ and the average was calculated every $15 \mathrm{~min}$; data was stored in a data logger (CR10X, Campbell, Logan, USA).

The parameters measured were: i) external solar radiation, temperature and relative humidity of the external air, the air inside the greenhouse and the air near the plants; ii) temperature of the growing substrate; iii) flow and return temperature and volumetric flow rate of the heated water from the external tank to the internal tank; iv) flow and return temperature of the heating water over the rows of pots.
The temperature and relative humidity of the external air, the air inside the greenhouse and the air near the plants was measured using thermistors [Tecno.el srl, Formello (RM), Italy]. The soil temperature was also detected using thermistors (Tecno.el s.r.l.).

Solar radiation was measured using a pyranometer (model 848, Eppley Laboratory, Newport, RI, USA) in the 0.3-3 mm wavelength range.

The temperature of the water flowing inside the pipes was measured by means of PT100 (Tecno.el s.r.1., Formello, Rome, Italy). The volumetric flow rate at which water flowed through a pipe was detected by a volume measuring meter (model MTH3, GWF MessSysteme AG, Lucerne, Switzerland). Balancing valves [Caleffi S.p.A., Fontaneto d'Agogna (NO), Italy] adjusted the flow rate of fluid flowing into the pipes in the cultivation area to ensure the operation of the system in the optimal design conditions.

\section{Experimental test}

In winter 2020-2021 an experimental test was performed to compare the growth of plants cultivated using three different localized heat distribution systems. Plants cultivated without any localized heating system were used as control. The test was carried out on Roman lettuce from December 17, 2020 to March 2, 2021.

An experimental block scheme was used for the agronomic tests, with 12 replications. The growth of the plants, by evaluating height and number of leaves per plant, was periodically monitored from transplanting to the beginning of the harvest. All the plants were grown with the same agronomic techniques.

\section{Results}

Solar energy gathered during daytime was collected in both tanks, for a total of $3000 \mathrm{~L}$. During the night, the stored thermal energy was used for plant heating. Weather conditions strongly affected thermal storage. Figure 3 shows the energy captured by the solar collectors and stored in the $1000-\mathrm{L}$. tank on $1^{\text {st }}$ February 2021. The solar energy collected during the entire day was equal to 37.2 MJ, while the energy delivered to the plants from one line with the plate system was $134.4 \mathrm{MJ}$ and from one line of underground pipes was 168.7 MJ. The remaining energy necessary for

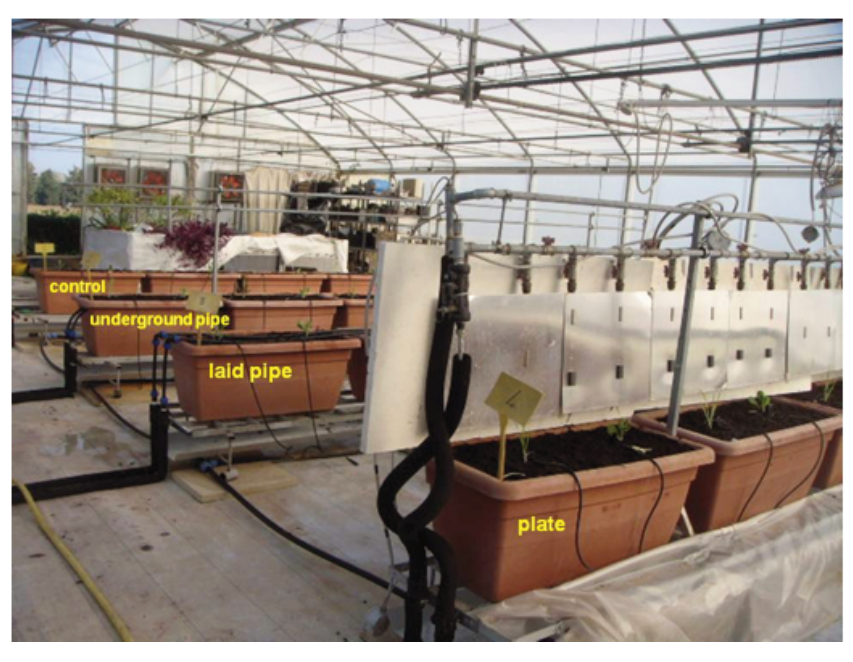

Figure 2. Heat distribution systems near the plants tested during 2020 inside the greenhouse at the University of Bari. 
plant heating over all the lines was provided by the heat pump. As expected, the heat pump compensated for the intermittent supply of the renewable sources.

The use of a heat localized distribution system ensures lower dispersion of the produced energy. The values of air and soil temperature in the three heat distribution systems and in the control were analysed. Figures 4 and 5 show air and soil temperature recorded when greenhouse air temperature was lower than $15^{\circ} \mathrm{C}$, for three days (16-18 January 2021). This period was particularly cold with a mean external air temperature of $3.9^{\circ} \mathrm{C}$ and a mean greenhouse air temperature equal to $9.0^{\circ} \mathrm{C}$. Air and soil temperature differences between the three localised heating systems and the control were evaluated. Regarding the air temperature (Figure $4)$, it was found that the highest heating $\left(0.3^{\circ} \mathrm{C}\right)$ was obtained by using the plate system, while the temperature was $0.5^{\circ} \mathrm{C}$ lower than that of the control system for the underground pipe system. Air temperature increases equal to $3.6 \%$ and to $3.5 \%$ were found for the plate and laid pipe systems, respectively, while a decrease of $6.7 \%$ was recorded for the underground pipe system.

With regard to the soil temperature (Figure 5), the highest increase $\left(8.0^{\circ} \mathrm{C}\right)$ was recorded for the underground pipe system, lower increases for the laid pipe system $\left(2.2^{\circ} \mathrm{C}\right)$ and the plate system $\left(0.3^{\circ} \mathrm{C}\right)$. In percentage terms, the underground pipe allowed to reach a soil temperature increase of $92.0 \%$, the laid pipe and the plate increases of $25.2 \%$ and $3.9 \%$, respectively.

Overall, it can be observed that the laid pipe system was an intermediate solution between the three systems both for air and soil heating. The plate system was the best for air temperature increasing, while the underground pipe system was the best for soil heating. The choice of one localized distribution system over another can also be depend by the cultivated crop species.

Table 1 reports data concerning harvest and the increase in the height and number of leaves of lettuce plants compared to the initial values recorded at transplanting. The increase in the height and number of leaves was assessed over the 55 days following the transplant up to the day of the first harvest. Three harvests were performed at 55, 68 and 75 days after transplanting. The values at harvest were evaluated as the average of all measurements carried out during the three harvests.

In the first 55 days after transplanting, the underground pipe heat distribution system had always allowed lettuces to grow more, while the lowest growth rate was recorded with no local heating (control). This behaviour can be explained by the fact that the heating of the soil, compared to the heating of the air, influenced plant growth more. The heat distribution system with a laid pipe heated both the growing substrate and the air near the plant itself, while the plate localized system heated the plants by radiative surfaces. After 55 days after transplanting, the first harvest accounted for $85 \%$ of lettuce heated with the underground tube and only $19 \%$ of the lettuce grown without any local heating (control). Localized soil heating systems contributed significantly to an earlier harvest by almost 2 weeks. The anticipation of the harvest is related to the highest increase of soil temperature recorded for the underground pipe.

To the authors' knowledge, there are no studies in literature which analyse a similar greenhouse polygeneration heating system, so the results obtained could not be compared to the results obtained by other researchers. Our research work was focused on greenhouse heating, but the described methodology and approach can be extended to smart communities, energy districts, industrial areas, etc. The results obtained using the polygeneration system could provide a decision support tool and different technical options to energy planners and operators. The use of a polygener-

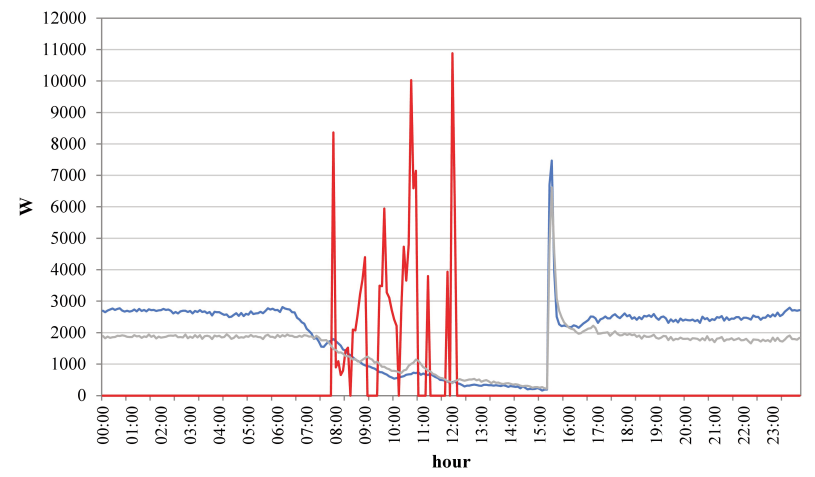

Figure 3. Thermal energy gathered by the solar collectors and stored in the 1000-L. tank (solar collectors, red line), heating energy delivered to the cultivation area from one line of the plates system (plate, grey line) and from one line of the underground pipes (underground pipe, blue line).

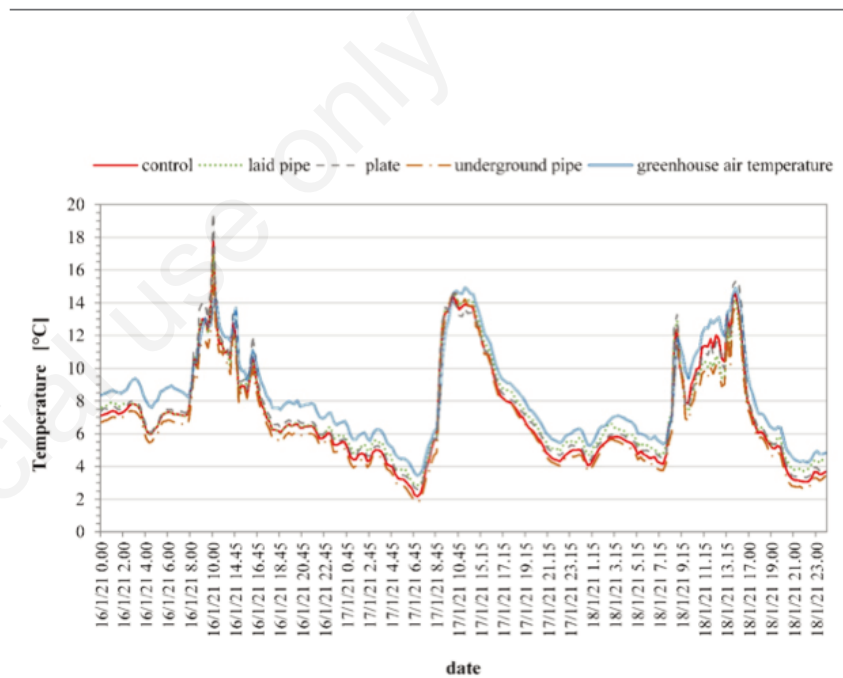

Figure 4. Air temperature in the four systems and greenhouse air temperature, 16-18 January 2021.

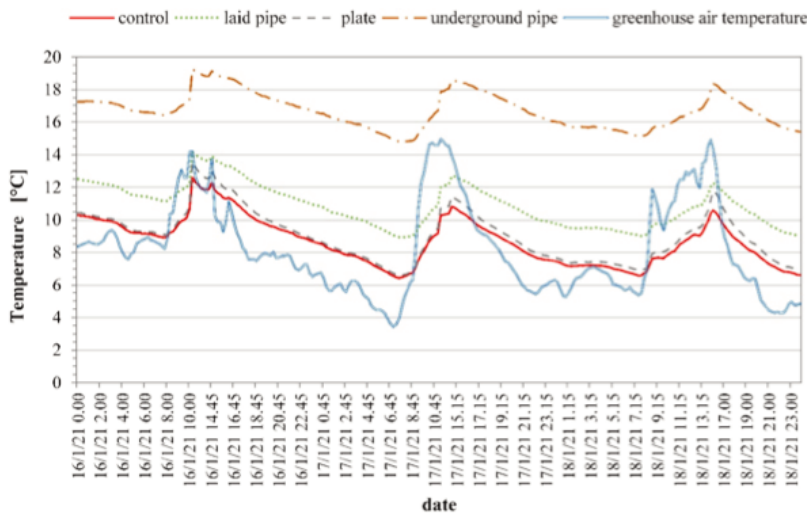

Figure 5. Soil temperature in the four systems and greenhouse air temperature, 16-18 January 2021. 
Table 1. Winter lettuce: height increase; leaves increase; average weight and cumulated harvest.

\begin{tabular}{|c|c|c|c|c|}
\hline & Control & Plate & Underground pipe & Laid pipe \\
\hline Initial height (cm) & $9.25^{\mathrm{a}}$ & $9.04^{\mathrm{a}}$ & $8.75^{\mathrm{a}}$ & $8.83^{\mathrm{a}}$ \\
\hline Height increase at 28/12/2020 (cm) & $0.33^{b}$ & $0.58^{\mathrm{ab}}$ & $1.04^{\mathrm{a}}$ & $0.50^{\mathrm{b}}$ \\
\hline Height increase at 13/1/2021 (cm) & $1.16^{\mathrm{c}}$ & $2.91^{\mathrm{b}}$ & $4.70^{\mathrm{a}}$ & $2.70^{\mathrm{b}}$ \\
\hline Height increase at 04/02/2021 (cm) & $7.16^{\mathrm{c}}$ & $10.08^{b}$ & $11.79^{\mathrm{a}}$ & $9.45^{\mathrm{b}}$ \\
\hline Height increase at 10/02/2021 (cm) & $9.54^{\mathrm{b}}$ & $11.95^{\mathrm{a}}$ & $12.91^{\mathrm{a}}$ & $11.66^{\mathrm{a}}$ \\
\hline Height increase at harvest (cm) & $11.79^{a}$ & $12.83^{\mathrm{a}}$ & $13.29^{\mathrm{a}}$ & $12.29^{\mathrm{a}}$ \\
\hline Initial number of leaves & $4.83^{\mathrm{b}}$ & $5.5^{\mathrm{a}}$ & $5.33^{\mathrm{ab}}$ & $4.75^{b}$ \\
\hline Leave increase at 28/12/2020 & $1.00^{\mathrm{b}}$ & $1.16^{\mathrm{ab}}$ & $1.58^{\mathrm{a}}$ & $1.33^{\mathrm{ab}}$ \\
\hline Leave increase at 13/1/2021 & $4.16^{\mathrm{c}}$ & $4.58^{\mathrm{bc}}$ & $6.08^{\mathrm{a}}$ & $5.75^{\mathrm{ab}}$ \\
\hline Leave increase at 04/02/2021 & $10.25^{\mathrm{c}}$ & $11.25^{\mathrm{bc}}$ & $13.58^{\mathrm{a}}$ & $12.50^{\mathrm{ab}}$ \\
\hline Leave increase at 10/02/2021 & $12.66^{\mathrm{c}}$ & $14.16^{\mathrm{bc}}$ & $17.58^{\mathrm{a}}$ & $15.08^{b}$ \\
\hline Leave increase at harvest & $17.41^{\mathrm{ab}}$ & $14.66^{\mathrm{c}}$ & $18.16^{\mathrm{a}}$ & $15.66^{\mathrm{bc}}$ \\
\hline Average lettuce weight at harvest (g) & $234.58^{\mathrm{ab}}$ & $198.5^{b}$ & $275.33^{\mathrm{a}}$ & $193.41^{\mathrm{b}}$ \\
\hline Yield at 10/02/2021 (g) & 536 & 1407 & 2813 & 1884 \\
\hline$\%$ of yield harvested on the total yield & $19 \%$ & $59 \%$ & $85 \%$ & $81 \%$ \\
\hline Cumulated yield at 23/02/2021 (g) & 2523 & 2085 & 3014 & 2111 \\
\hline$\%$ of yield harvested on the total yield & $90 \%$ & $88 \%$ & $91 \%$ & $91 \%$ \\
\hline Cumulated yield at 02/03/2021 (g) & 2815 & 2382 & 3304 & 2321 \\
\hline
\end{tabular}

${ }^{a-c}$ Mean values in a row with a different superscript letter statistically differ at $\mathrm{P}<0.05$ using Tukey-Kramer test.

ation system could improve the global energy and environmental performance in the short and long term.

\section{Conclusions}

The choice of an appropriate heating system for a greenhouse is influenced by several parameters such as type of climate, crop to be grown, investment-related costs, installation, operation and maintenance, ease of operation, reliability, equipment lifetime, electricity consumption, and so on. The polygeneration system, composed of a solar system and an air-water heat pump, described in this paper, was designed to increase the air temperature inside a greenhouse in wintertime. The integration of the solar heating technology with an air-water heat pump could maximize the utilization of solar energy by overcoming the irregular intensity of solar irradiance. This experimental study focused on three different localised heating systems (laid pipe, underground pipe and plate) to find out the most appropriate technology. The plate system was the best for air temperature increasing, while the underground pipe system was the best for soil heating. The highest increase of soil temperature $\left(8.0^{\circ} \mathrm{C}\right)$ recorded with the underground pipe was decisive for the anticipation of the harvest by almost 2 weeks. Our work showed the effectiveness of localized energy distribution in greenhouses, which is a novelty that can be further explored in future research.

\section{References}

Ahamed M.S., Guo H., Tanino K. 2019. Energy saving techniques for reducing the heating cost of conventional greenhouses. Biosyst. Engine. 178:9-33.

Barbaresi A., Maioli V., Bovo M., Tinti F., Torreggiani D.,
Tassinari P. 2020. Application of basket geothermal heat exchangers for sustainable greenhouse cultivation. Renew. Sustain. Energy Rev. 129:109928.

Bazgaou A., Fatnassi H., Bouharroud R., Ezzaeri K., Gourdo L., Wifaya A., Demrati H., Elame F., Carreño-Ortega Á., Bekkaoui A., Aharoune A., Bouirden L. 2021. Effect of active solar heating system on microclimate, development, yield and fruit quality in greenhouse tomato production. Renew. Energy 165:237-50.

Bibbiani C., Fantozzi F., Gargari C., Campiotti C.A., Schettini E., Vox G. 2016. Wood biomass as sustainable energy for greenhouses heating in Italy. Agr. Agric. Sci. Procedia 8:637-45.

Cuce E., Harjunowibowo D., Cuce P. M. 2016. Renewable and sustainable energy saving strategies for greenhouse systems: a comprehensive review. Renew. Sustain. Energy Rev. 64:34-59.

Fabrizio E. 2012. Energy reduction measures in agricultural greenhouses heating: envelope, systems and solar energy collection. Energy Build. 53:57-63.

Gorjian S., Ebadi H., Najafi G., Singh Chandel S., Yildizhan H. 2021. Recent advances in net-zero energy greenhouses and adapted thermal energy storage systems. Sustain. Energy Technol. Assess. 43:100940.

Hernández J., Bonachela S., Granados M.R., López J.C., Magán J.J., Montero J.I. 2017. Microclimate and agronomical effects of internal impermeable screens in an unheated Mediterranean greenhouse. Biosyst. Engine. 163:66-77.

Puglisi G., Vox G., Kavga A., Convertino F., Blanco I., Schettini E. 2019. Solar cooling: A renewable energy solution. Riv. Studi Sosten. 2:231-47.

Puglisi G., Vox G., Campiotti C.A., Scarascia Mugnozza G., Schettini E. 2020. Experimental results of a solar cooling system for greenhouse climate control. Acta Hortic. 1296:110714.

Schettini E, Vox G. 2012. Effects of agrochemicals on the radio- 
metric properties of different anti-UV stabilized EVA plastic films. Acta Hortic. 956:515-22.

Sethi V.P., Sharma S.K. 2008. Survey and evaluation of heating technologies for worldwide agricultural greenhouse applications. Solar Ener. 82:832-59.

Vox G., Schettini E., Scarascia-Mugnozza G. 2005. Radiometric properties of biodegradable films for horticultural protected cultivation. Acta Hortic. 691:575-82.
Vox G., Schettini E., Lisi Cervone A., Anifantis A.S. 2008. Solar thermal collectors for greenhouse heating. Acta Hortic. 801:787-94.

Vox G., Blanco I., Scarascia Mugnozza G., Schettini E., Bibbiani C., Viola C., Campiotti C.A. 2014. Solar absorption cooling system for greenhouse climate control: technical evaluation. Acta Hortic. 1037:533-8. 